\title{
IMPACT OF SOWING DATE OF WHEAT UNDER WATER STRESS IN NORTH NILE DELTA-EGYPT \\ El-Hadidi, E.M. ${ }^{1}$; G. Labib ${ }^{1}$ and Amira A. Kasem ${ }^{2}$ \\ 1- Soils Dept., Fac. of Agric. Mansoura Univ. \\ 2-Soils, Water and Environment Res. Institute, A.R.C., Giza.
}

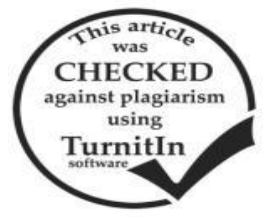

\section{ABSTRACT}

The present investigation was conducted at Sakha Agricultural Research Station, Kafr El-Sheikh Governorate. The station is sited at $31^{0_{\circ}}-57^{-} / \mathrm{N}$ latitude and $30^{\circ}-57^{-}$longitude. It has an elevation of about $20 \mathrm{~m}$ above sea level and it represents the conditions and circumstances of the middle north Nile Delta.

A field experiment was carried out during the season 2014/2015 to study the effect of number of irrigations and sowing date on wheat yield, its components and some water relationships. A split plot design with four replications was used. Sowing date were 15/11 $\left(D_{1}\right), 30 / 11\left(D_{2}\right)$ and 15/12 $\left(D_{3}\right)$ occupied the main plots, while irrigation regime were $I_{1}=5$ irrigations , $I_{2}=$ 4 irrigations and $\mathrm{I}_{3}=3$ irrigations, arranged in sub-plots.

The obtained results can be summarized as follows:

The highest values of water applied and water consumptive use were recorded under $\left(\mathrm{I}_{1}\right)$.On the contrary, the lowest values were recorded under treatment, $\left(\mathrm{I}_{3}\right) .15^{\text {th }}$ November as a sowing date significantly increased grain yield, straw yield, spike length, number of tiller, plant height and 1000 grain weight by $18.6,17.4,26.7,17.8,9.9$ and $20.3 \%$ compared to sowing on $15^{\text {th }}$ December $\left(\mathrm{D}_{3}\right)$. Also sowing on $15^{\text {th }}$ November significantly increased water productivity by $27.2 \%$.

Keywords: wheat, number of irrigation, sowing date, water productivity.

\section{INTRODUCTION}

In Egypt, the future of agriculture is hard to project even assuming the continuation of current climate conditions. The task is made all the more difficult by the possibility of significant warming expected to result from the greenhouse effect. Egypt appears to be particularly vulnerable to climate change because of its dependence on the Nile as its primary water source, its large traditional agricultural base, and its long coastline, which is already undergoing both intensifying development and erosion.

Ouda et al., 2005 studied six sowing dates $\left(1^{\text {st }}\right.$ of October, $15^{\text {th }}$ of October, $1^{\text {st }}$ of November, $15^{\text {th }}$ of November, $1^{\text {st }}$ of December, and $30^{\text {th }}$ of December) on wheat yield (sakha 93), in addition to water stress at different growth stages they indicated that sowing wheat in October reduced grain yield by about $10 \%$. Whereas, delay of sowing date till to the end of December decreased yield by about $16 \%$. The highest grain yield was obtained when wheat was sown on the first of December, followed by $15^{\text {th }}$ of November, compared with other sowing dates. Zhang and Oweis, (1999) reported that wheat response to water stress is more sensitive from stem- elongation to booting, followed by anthesis and grain- filling stages.

Eid et al 1997 and El-Marsafawy et al 1998 showed that delay of wheat sowing, date up to the end of December reduced wheat yield as a result of high temperature, which reduced season length.

The objective of this work was to

1- evaluate the effects of the sowing date and number of irrigation on yield and water productivity of winter wheat in north Nile Delta in Egypt.

2- determine the optimum sowing date for wheat grown under the condition of North Nile Delta Region.

\section{MATERIALS AND METHODS}

The present investigation was conducted at Sakha Agricultural Research Station, Kafr El-Sheikh Governorate. The station is sited at $31^{0_{0}}-57^{-} / \mathrm{N}$ latitude and $30^{\circ}-57^{-}$longitude. It has an elevation of about $20 \mathrm{~m}$ above sea level and it represents the conditions and circumstances of the middle north Nile Delta.

Sakha weather data had been recorded daily and their mean monthly values are presented in Table 1 .

A split- plot design with four replicates was used. Sowing date occupied the main plots, while irrigation regime arranged in sub-plots. The sowing dates were $15 / 11\left(D_{1}\right), 30 / 11\left(D_{2}\right)$ and $15 / 12\left(D_{3}\right)$. Sub plots were devoted to irrigation regime treatments, $\mathrm{I}_{1}=5$ irrigations , $\mathrm{I}_{2}=4$ irrigations and $\mathrm{I}_{3}=3$ irrigations. Harvesting was done in 1/5/2015Each individual plot was $7 \mathrm{~m} \times 7.5 \mathrm{~m}=52.5 \mathrm{~m}^{2}=1 / 80 \mathrm{fed}$. No. of plots $=3 \times 3 \times 4=36$ plots. Soil texture of experimental field was clayey $(51.1 \%$ clay, $33.4 \%$ silt and $15.3 \%$ sand) in texture and non-saline, non alkaline. Sowing was done on the $15^{\text {th }}, 30^{\text {th }}$ of November and $15^{\text {th }}$ of December All cultural practices were done as recommended by the Egyptian Ministry of Agricultural and Land Reclamation except the two factors of study i.e. irrigation number and sowing date. Wheat grains (Triticum aestivum L.) Maser 2. at a rate of $60 \mathrm{~kg}^{-\mathrm{fed}^{-1}}$ were sown.

Water applied (WA):

Irrigation water was measured by a constructed rectangular weir with a discharge of $0.01654 \mathrm{~m}^{3} \mathrm{sec}^{-1}$ at effective head of $10 \mathrm{~cm}$. Water applied (WA) was calculated as mentioned by Giriapa (1983):

$\mathrm{WA}=\mathrm{IW}+\mathrm{R}+\mathrm{S}$

Where:

$\mathrm{Wa}=$ Irrigation water applied, $\mathrm{m}^{3} / \mathrm{fed}$

$\mathrm{R}=$ rainfall, $\mathrm{m}^{3} / \mathrm{fed}$

$\mathrm{S}=$ Amount of soil moisture contributed to consumptive use from the

soil profile either as stored moisture in root zone and/or that contributed from the shallow groundwater table, $\mathrm{m}^{3} /$ fed 
Table (1): Sakha agro-meteorological data during 2014/2015 season.

\begin{tabular}{|c|c|c|c|c|c|c|c|c|c|c|}
\hline \multirow[b]{2}{*}{ Seasons } & \multirow[b]{2}{*}{ Months } & \multicolumn{3}{|c|}{ Air temperature $\left({ }^{\circ} \mathrm{C}\right)$} & \multicolumn{3}{|c|}{ Relative humidity (\%) } & \multirow{2}{*}{$\begin{array}{l}\text { Wind speed } \\
\qquad \mathrm{m} \mathrm{s}^{-1}\end{array}$} & \multirow{2}{*}{$\begin{array}{c}\text { Pan } \\
\text { Evap., } \\
\text { mm/ day }\end{array}$} & \multirow{2}{*}{$\begin{array}{c}\text { Rain } \\
\text { Mm/ } \\
\text { month }\end{array}$} \\
\hline & & Max. & Min. & Mean & Max. & Min. & Mean & & & \\
\hline & Nov & 24.30 & 13.79 & 19.05 & 87.80 & 60.50 & 74.15 & 0.78 & 2.77 & 24.6 \\
\hline & Dec. & 22.27 & 9.72 & 16.00 & 88.60 & 63.50 & 76.05 & 0.53 & 1.72 & 5.70 \\
\hline & Jan. & 18.79 & 6.46 & 12.63 & 88.10 & 61.10 & 74.60 & 0.82 & 2.70 & 52.55 \\
\hline$\cong$ & Feb. & 19.01 & 7.65 & 13.33 & 86.80 & 62.70 & 74.75 & 0.84 & 2.90 & 38.8 \\
\hline$\overline{\mathrm{d}}$ & Mar. & 22.69 & 11.69 & 17.19 & 82.36 & 58.82 & 70.59 & 1.01 & 3.23 & 15.25 \\
\hline 于 & Apr . & 25.64 & 13.70 & 19.67 & 78.30 & 48.50 & 63.40 & 1.11 & 6.07 & 35.85 \\
\hline กิ & May & 30.19 & 18.79 & 24.49 & 77.3 & 46.1 & 61.7 & 1.33 & 7.15 & 0.00 \\
\hline
\end{tabular}

* Source: meteorological station at Sakha 31-07' N Latitude, 30-57'E Longitude, N.elevation 6 m.

Table (2): Mechanical and physical analysis for the experimental site before cultivating the crop.

\begin{tabular}{|c|c|c|c|c|c|c|c|c|c|}
\hline \multirow{3}{*}{$\begin{array}{l}\text { Soil depth } \\
\text { (cm) }\end{array}$} & \multicolumn{9}{|c|}{ Physical characteristics } \\
\hline & \multicolumn{3}{|c|}{ Mechanical analysis } & \multirow[b]{2}{*}{ Texture class } & \multirow{2}{*}{$\begin{array}{c}\text { Bulk } \\
\text { density } \\
\mathrm{Mg} / \mathrm{m}^{3}\end{array}$} & \multirow{2}{*}{$\begin{array}{c}\text { Total } \\
\text { porosity } \\
\%\end{array}$} & \multirow{2}{*}{$\begin{array}{c}\text { Field } \\
\text { capacity } \\
\%\end{array}$} & \multirow{2}{*}{$\begin{array}{c}\text { PWP } \\
\%\end{array}$} & \multirow{2}{*}{$\begin{array}{c}\text { A.W } \\
\%\end{array}$} \\
\hline & Sand & Silt & Clay & & & & & & \\
\hline $0-15$ & 13.3 & 32.3 & 54.4 & Clayey & 1.26 & 52.45 & 46.50 & 25.69 & 20.81 \\
\hline $15-30$ & 18.2 & 36.2 & 45.6 & Clayey & 1.30 & 50.94 & 40.87 & 21.66 & 19.21 \\
\hline $30-45$ & 20.4 & 39.4 & 40.2 & Clay loam & 1.29 & 51.32 & 39.40 & 20.86 & 18.54 \\
\hline $45-60$ & 19.1 & 41.5 & 39.4 & Clay loam & 1.38 & 47.92 & 37.39 & 19.78 & 17.61 \\
\hline Mean & 17.75 & 37.35 & 44.9 & & 1.31 & 50.66 & 41.04 & 21.99 & 18.51 \\
\hline
\end{tabular}

$\overline{\text { PWP }}=$ Permanent wilting point, $\mathrm{AW}=$ Available water, $\mathrm{Mg}=\operatorname{Mega}$ gram $\left(10^{6} \mathrm{~g}\right)$

Consumptive use (CU)

Soil moisture content was determined gravimetrically as average of two sub-samples of four depths $(0-15,15-30,30-45$, and 45-60 cm) just before and after each irrigation as well as before harvesting for all treatments to determine water consumptive use $(\mathrm{Cu})$ according to Hansen et al. (1980).

$\mathrm{CU}=\sum_{i=1}^{\mathrm{n}=4} \frac{\theta_{2}-\theta_{1}}{100} \times \mathrm{D} \times \mathrm{Bd}$

Where:

$\mathrm{CU}=$ Water consumptive use in $\mathrm{cm}$.

$\mathrm{D}=$ Soil depth $(\mathrm{cm})$.

$\mathrm{Bd}=$ Bulk density, $\mathrm{Mgm}^{-3}$ (Mega gram $\left.=\left(10^{6} \mathrm{~g}\right)\right)$

$\theta_{2}=$ Soil moisture content after irrigation.

$\theta_{1}=$ Soil moisture content before irrigation.

To monitor water table fluctuation, nine observation wells were installed However, amounts and timing were recorded. Irrigation scheduling for other treatments was based on crop evapotranspiration $\left(\mathrm{ET}_{\mathrm{c}}\right)$. was calculated from the reference evapotranspiration $\mathrm{ET}_{\mathrm{o}}$ and the FAO crop coefficients $(\mathrm{Kc})$ for wheat (Allen et al., 1998). $\mathrm{ET}_{0}$ was calculated using the Penman-Monteith equation.(CROPWAT program) ET $_{c}$ was computed weekly

Crop water use:

ETc $=$ ETo $x$ Kc

Where:

$\mathrm{ETc}=$ crop evapotranspiration or crop water use $(\mathrm{mm})$

$\mathrm{ETo}=$ calculated reference ET for grass $(\mathrm{mm})$ available $\mathrm{Kc}=$ crop coefficient

The reference evapotranspiration (ETo)

ETo was calculated by CROPWAT model v.8.0 (Smith, 1992) based on the agro-metrological data collected for the studied area.

\section{Crop coefficient Kc}

Values of the Kc were quoted from FAO ( Allen et.al., 1998). The four distinct growing stages of growing period are initial (35 days), crop establishment (60 days), mid-season (70 days) and late season (40 days). The corresponding values are $0.4,0.75,1.05$, and 0.6 respectively. The length of growing stages of wheat identified with respect to (Allen, et al., 1998 ).

Contribution of the ground water table $(\mathrm{S})$ :

Water movement by capillary rise from water table into active plant root zone is recognized as an important supplementary water resource for irrigation. The contribution of groundwater as percentage of the consumptive use was calculated as follow:

Where :

$$
\mathbf{S}=\left(\mathbf{E T}_{\mathbf{c}}-\mathbf{S M D}\right)
$$

$\mathrm{ET}_{\mathrm{c}}=$ Crop evapotranspiration $=\mathrm{ET}_{0} \times \mathrm{K}_{\mathrm{c}}$, $\mathrm{mm}$

$\mathrm{SMD}=$ Soil moisture depletion., $\mathrm{mm}$

Fluctuation of ground water table:

In order to establish the diagram of ground water table fluctuation during the growing seasons under wheat crop, a nine observation wells were installed along different treatment. Perforated plastic tube with each observation well was two inches in diameter and two meter long. Daily reading of ground water table was recorded by the aid of a metallic sounder that fixed in a sealed tape to measure the water table depth

Yield and yield components:

number of tillers, length of spike, height of plant, 1 000-grain weight, grain and straw yield of wheat at maturity were determined from central area of each subplot to avoid any effect and recorded The grains were separated from the straw, and the grains were weighed. Grain yield was calculated based on the 
adjustment to grain moisture content of $140 \mathrm{~g} \mathrm{~kg}^{-1}$. Biomass yield express grain plus straw yields.

Water measurements.

Water productivity (WP) was calculated according to Molden, (1997)

WP $\left(\mathrm{kg} \mathrm{m}^{-3}\right.$ or $\$ \mathrm{~m}^{-3}=\frac{\text { Output derived from water use }\left(\mathrm{kg} / \mathrm{m}^{3} \text { or } \$ / \mathrm{m}^{3}\right.}{\text { Water input }\left(\mathrm{m}^{3}\right)}$

The obtained data were statistically analyzed by analysis of variance, analysis was done according to Gomez and Gomez (1984) .Means of the treatment were compared by the least significant difference (LSD) at $5 \%$ level of significance which developed by Waller and Duncan (1969)

\section{RESULTS AND DISCUSSION}

\section{Seasonal water applied (Wa)}

Under the conditions of the present study, the seasonal water applied (Wa) consists of the three components; irrigation water (IW), rainfall (R) and contribution of water table (S). Wheat as a winter crop received rainfall of $172.7 \mathrm{~mm}=725.34 \mathrm{~m}^{3}$ Water applied decreased with decreasing number of irrigation Irrigation water (IW):

As shown in Tables (3) \& (4) the total number of irrigation events were 5,4 and 3 for $\mathrm{I}_{1}, \mathrm{I}_{2}$, and $\mathrm{I}_{3}$ respectively, including sowing irrigation. Amounts of irrigation water (IW) are tabulated in Table (3). Mean values of irrigation water were $2172.96,1826.76$ and1538.32 $\mathrm{m}^{3} \mathrm{fed}^{-1}$. for $\mathrm{I}_{1}, \mathrm{I}_{2}$ and $\mathrm{I}_{3}$ respectively as the irrigation treatments. Irrigation water for $I_{3}$ treatment was the lowest, and the amount for $\mathrm{I}_{1}$ treatment was the highest. These data indicate that using three irrigation ( $\mathrm{I}_{3}$ irrigation treatment) saved water by about $29.2 \%$ $\left(634.64 \mathrm{~m}^{3}\right)$ compared with irrigation treatment $I_{1}$ (the conventional irrigation), while for sowing date treatments mean values of irrigation water were $2005.44,1814.28$ and $1718.32 \mathrm{~m}^{3} \mathrm{fed}^{-1}$. for $\mathrm{D}_{1}, \mathrm{D}_{2}$ and $\mathrm{D}_{3}$.

Table (3): Seasonal irrigation (IW), rainfall (R), contribution from water table (S), seasonal water applied (Wa)and contribution of ground water as percentage $(\%)$ for wheat

\begin{tabular}{|c|c|c|c|c|c|c|c|}
\hline \multirow{2}{*}{\multicolumn{2}{|c|}{ Treatments }} & \multicolumn{2}{|c|}{ IWm } & \multirow{2}{*}{$\underset{\mathbf{m}^{3} \text { fed }^{-1}}{R}$} & \multirow{2}{*}{$\begin{array}{c}S \\
\mathbf{m}^{3} \text { fed }^{-1}\end{array}$} & \multirow{2}{*}{$\begin{array}{c}\text { WA } \\
\text { m }^{3} \text { fed }^{-1} \\
\end{array}$} & \multirow{2}{*}{$\mathbf{S \%}$} \\
\hline & & No & $\mathrm{m}^{\mathbf{3}} \mathrm{fed}^{-1}$ & & & & \\
\hline \multirow{3}{*}{$\mathrm{D}_{1}$} & $\mathrm{I}_{1}$ & 5 & 2355.36 & 725.34 & 0 & 3080.70 & 0.00 \\
\hline & $\mathrm{I}_{2}$ & 4 & 1922.64 & 725.34 & 86.1 & 2734.08 & 4.48 \\
\hline & $\mathrm{I}_{3}$ & 3 & 1738.32 & 712.34 & 139.82 & 2590.48 & 8.04 \\
\hline \multirow{3}{*}{$\mathrm{D}_{2}$} & $\mathrm{I}_{1}$ & 5 & 2141.76 & 725.34 & 0 & 2867.10 & 0.00 \\
\hline & $\mathrm{I}_{2}$ & 4 & 1802.76 & 725.34 & 94.08 & 2622.18 & 5.22 \\
\hline & $\mathrm{I}_{3}$ & 3 & 1498.32 & 725.34 & 139.78 & 2363.44 & 9.33 \\
\hline \multirow{3}{*}{$\mathrm{D}_{3}$} & $\mathrm{I}_{1}$ & 5 & 2021.76 & 725.34 & 0 & 2747.10 & 0.00 \\
\hline & $\mathrm{I}_{2}$ & 4 & 1754.88 & 725.34 & 125.96 & 2606.18 & 7.18 \\
\hline & $\mathrm{I}_{3}$ & 3 & 1378.32 & 725.34 & 200.74 & 2304.40 & 14.56 \\
\hline
\end{tabular}

Table (4)Irrigation water in $\left(\mathrm{m}^{3} \mathrm{fed}^{-1}\right)$ as related to interaction between sowing date and number of irrigation

\begin{tabular}{lcccc}
\hline Treatments & $\mathbf{D}_{\mathbf{1}}$ & $\mathbf{D}_{\mathbf{2}}$ & $\mathbf{D}_{\mathbf{3}}$ & I-mean \\
\hline $\mathrm{I}_{1}$ & 2355.36 & 2141.76 & 2021.76 & 2172.96 \\
$\mathrm{I}_{2}$ & 1922.64 & 1802.76 & 1754.88 & 1826.76 \\
$\mathrm{I}_{3}$ & 1738.32 & 1498.32 & 1378.32 & 1538.32 \\
D-mean & 2005.44 & 1814.28 & 1718.32 & \\
\hline
\end{tabular}

Water consumptive use $(\mathrm{CU})$.

Crop consumptive use (CU) was determined directly from the soil moisture depletion (S.M.D) in the effective root zone. Values of seasonal $\mathrm{CU}$ in $\mathrm{cm}$ are presented in Table $\left(5_{\mathrm{a}}\right.$ and $\left.5_{\mathrm{b}}\right)$ for wheat during the growing season 2014/2015. The obtained results showed that the seasonal CU values were greatly affected by number of irrigation, where $\mathrm{CU}$ values decreased with increasing the irrigation interval. Seasonal values of CU were, 42.73, 37.04and $32.51 \mathrm{~cm}$ for the treatments $I_{1}, I_{2}$, and $I_{3}$ respectively.. Results in Table (5) showed that, values of the CU were higher under $\mathrm{D}_{1}$ than that under other one. Mean values of $\mathrm{CU}$, were $38.98,37.56$ and $35.75 \mathrm{~cm}$ for $\mathrm{D}_{1}, \mathrm{D}_{2}$ and $\mathrm{D}_{3}$ respectively.

Table $\left(5_{\mathrm{a}}\right)$ : Contribution of water table(S) to wheat crop $\mathrm{Cu}(\mathrm{cm})$ under different treatments in growing season 2014/2015.

\begin{tabular}{lllcc}
\hline Treatments & & ETc & S.M.D=CU & ETc-S.M.D=S \\
\hline & $\mathrm{I}_{1}$ & 40.6 & 43.5 & 0 \\
$\mathrm{D}_{1}$ & $\mathrm{I}_{2}$ & 40.6 & 38.55 & 2.05 \\
& $\mathrm{I}_{3}$ & 40.6 & 34.89 & 5.71 \\
& $\mathrm{I}_{1}$ & 40.6 & 42.8 & 0 \\
$\mathrm{D}_{2}$ & $\mathrm{I}_{2}$ & 40.6 & 37.36 & 3.24 \\
& $\mathrm{I}_{3}$ & 40.6 & 32.51 & 8.09 \\
& $\mathrm{I}_{1}$ & 40.6 & 41.9 & 0 \\
$\mathrm{D}_{3}$ & $\mathrm{I}_{2}$ & 40.6 & 35.22 & 5.38 \\
& $\mathrm{I}_{3}$ & 40.6 & 30.13 & 10.47 \\
\hline
\end{tabular}


Table ( $5_{b}$ ) CU (S.M.D) as affected by the interaction between number of irrigation and sowing date

\begin{tabular}{lcccc}
\hline Treatment & $\mathbf{D}_{\mathbf{1}}$ & $\mathbf{D}_{\mathbf{2}}$ & $\mathbf{D}_{\mathbf{3}}$ & I-mean \\
\hline $\mathrm{I}_{1}$ & 43.50 & 42.80 & 41.90 & 42.73 \\
$\mathrm{I}_{2}$ & 38.55 & 37.36 & 35.22 & 37.04 \\
$\mathrm{I}_{3}$ & 34.89 & 32.51 & 30.13 & 32.51 \\
D-mean & 38.98 & 37.56 & 35.75 & \\
\hline
\end{tabular}

Fluctuation of water table depth during the growing seasons:

Table (6) represents the obtained results for effects of sowing date and irrigation intervals on maximum and minimum values of water table depth, for each observation well, under each treatment, which indicated the depth of water table reached the lowest value immediately before irrigation. While the maximum water depth reached at 2 days after irrigation. The irrigation interval in these study had strong effect on the behavior of the water table. The average maximum values of water table depth varied between 67 and $78 \mathrm{~cm}$. The corresponding values of the minimum water table depth were 95 and $114 \mathrm{~cm}$. In general, it could be summarized that the fluctuation of water table regime for wheat has the following interactions:

1- No clear effect was observed of various sowing date on the behavior of water table regime

2- Irrigation intervals have a main effect on the regime of water table. The long irrigation interval, the deepest water table was resulted and visa versa.

3- The distance from both the irrigation canal in the north and main surface drain in the south of the experiment area

Table(6):Maximum, Minimum and mean values of water table depth cm. during the growing season2014/2015

\begin{tabular}{cccccc}
\hline Treatments & & Observation well & Maxi & Mini. & Mean \\
\hline \multirow{3}{*}{$\mathrm{D}_{1}$} & $\mathrm{I}_{1}$ & 1 & 67 & 98 & 82.5 \\
& $\mathrm{I}_{2}$ & 2 & 75 & 104 & 89.5 \\
& $\mathrm{I}_{3}$ & 3 & 78 & 109 & 93.5 \\
$\mathrm{D}_{2}$ & $\mathrm{I}_{1}$ & 4 & 73 & 95 & 86.5 \\
& $\mathrm{I}_{2}$ & 5 & 70 & 105 & 87.5 \\
& $\mathrm{I}_{3}$ & 6 & 70 & 110 & 90 \\
$\mathrm{D}_{3}$ & $\mathrm{I}_{1}$ & 7 & 73 & 110 & 83.5 \\
& $\mathrm{I}_{2}$ & 8 & 72 & 114 & 91.5 \\
\hline
\end{tabular}

\section{Contribution of water table (\%):}

Table (7) represents the contribution of water table to wheat evapotranspiration during the 2014/2015 growing season. Data showed that by increasing irrigation water, less value was obtained. For the maximum irrigation water (treatment $I_{1}$ ) there was no contribution from water table. For the other treatments $\left(\mathrm{I}_{2}\right.$ and $\left.\mathrm{I}_{3}\right)$ average values of contribution are 3.56 and $8.09 \mathrm{~cm}$.

Grain yield $\left(\mathrm{kg} \mathrm{fed}^{-1}\right)$ :

Data showed significant effects of different sowing date .The highest grain and straw yields was obtained from $D_{1}\left(15^{\text {th }}\right.$ November $\left(2568 \& 6487 \mathrm{~kg} \mathrm{fed}^{-1}\right)$ while $15^{\text {th }}$ December, produced the lowest grain and straw yields of $\left(2090 \& 5356 \mathrm{~kg} \mathrm{fed}^{-1}\right)$ Table (8) These results agree with Shahzad et al.(2007) which obtained lower grain yield with delay in sowing due to shorter duration of growth and development.

On the other hand, the contribution was increased directly by increasing irrigation intervals. It was mention that under treatments which had relatively important values of water table contribution ( $\mathrm{I} 2$ and $\mathrm{I}_{3}$ ), the corresponding percentage ranged between 7.18 and $14.56 \%$. These findings are an agreement with those obtained by (Eid 2015)

Table( 7 ) Contribution of ground water table (S) as affected by the interaction between number of irrigation and sowing date

\begin{tabular}{lcccc}
\hline Treatment & $\mathbf{D}_{\mathbf{1}}$ & $\mathbf{D}_{\mathbf{2}}$ & $\mathbf{D}_{\mathbf{3}}$ & I-mean \\
\hline $\mathrm{I}_{1}$ & 0 & 0 & 0 & 0 \\
$\mathrm{I}_{2}$ & 2.05 & 3.24 & 5.38 & 3.56 \\
$\mathrm{I}_{3}$ & 5.71 & 8.09 & 10.47 & 8.09 \\
D-mean & 3.88 & 5.67 & 7.93 & \\
\hline
\end{tabular}

\section{Effect of sowing date:}

Mean values of grain and straw yields in $\mathrm{kg}^{-\mathrm{fed}^{-}}$ 1 of wheat as affected by sowing date are shown in Table (8) Sowing date significantly influenced grain and straw yields per fed. Mean values of grain and straw yields obtained by $\mathrm{D}_{1}, \mathrm{D}_{2}$ and $\mathrm{D}_{3}$ sowing date were 2568 , 2310 and $2090 \& 6487,5502$ and $5356 \mathrm{~kg} \mathrm{fed}^{-}$ ${ }^{1}$ respectivily. Values of grain and straw yields under all the irrigation number treatments had the descending order: $D_{1}>D_{2}>D_{3}$. The decrease percentage In grain and 
straw yields was $(10.0 \%$ and $18.6 \% \& 15.2 \%$ and 17.4 $\%$ ) under $\mathrm{D}_{2}$ and $\mathrm{D}_{3}$, respectively, compared with treatment $\mathrm{D}_{1}$.It means that sowing date in $15^{\text {th }}$ November cause higher increase on grain yield compared with other sowing dates

Effect of irrigation number of wheat on grain yield :

Regarding the effect of the irrigation number treatments on grain and straw yields the five irrigations numbers for $\left(I_{1}\right)$ treatments was greater than the other two treatments. Mean values of grain and straw yields obtained by $I_{1}, I_{2}$ and $I_{3}$ irrigation number are 2518 , 2313 and $2137 \& 6433,5679$ and $5232 \mathrm{~kg}$ fed ${ }^{1}$ respectivily Table (8) values of grain and straw yields under all the irrigation number treatments had the descending order: $I_{1}>I_{2}>I_{3}$. The decrease percentage on grain and straw yields was $(8.1 \%$ and $15.1 \% \& 11.7 \%$ and $18.6 \%$ ) under $\mathrm{I}_{2}$ and $\mathrm{I}_{3}$, respectively, compared with treatment $\mathrm{I}_{1}$.It means that 5 irrigation number cause higher increase in grain yield compared with other irrigation number treatments.

This occurred under each of the sowing dates.

Effect of interaction between sowing date and irrigation number:

The highest grain and straw yields was obtained by $\mathrm{I}_{1} \mathrm{D}_{1}$ treatment which gave $2861 \& 7236 \mathrm{~kg} \mathrm{fed}^{-1}$. The lowest yields was obtained by the $\mathrm{I}_{3} \mathrm{D}_{3}$ treatment which gave $1941 \& 4905 \mathrm{~kg} \mathrm{fed}^{-1}$ grain and straw yields respectively.

Spike length $(\mathrm{cm})$ :

The length of spike plays a vital role in wheat towards the grains spike ${ }^{-1}$ and finally the yield (Shahzad et al., 2007). As far as the sowing date is concerned, significant observations were recorded for the spike length. Sowing wheat on $15^{\text {th }}$ November produced the longest and statistically at par spike length of $13.3 \mathrm{~cm}$ Table(9).

Table(8)Effect of Sowing date (D) and irrigation number (I) on grain and straw yield of wheat (kg fed ${ }^{-1}$.) during 2014/2015 growing seasons.

\begin{tabular}{|c|c|c|c|c|c|c|c|c|}
\hline \multirow[t]{2}{*}{ Treatments } & \multicolumn{4}{|c|}{ Grain yield kg fed ${ }^{-1}$} & \multicolumn{4}{|c|}{ Straw yield kg fed ${ }^{-1}$} \\
\hline & $\mathrm{D}_{1}$ & $\mathrm{D}_{2}$ & $\mathrm{D}_{3}$ & I-mean & $\mathrm{D}_{1}$ & $\mathrm{D}_{2}$ & $\mathrm{D}_{3}$ & I-mean \\
\hline $\mathrm{I}_{1}$ & $2861 \mathrm{a}$ & $2434 \mathrm{a}$ & $2258 \mathrm{a}$ & 2518 & $7236 \mathrm{a}$ & $6144 \mathrm{a}$ & $5920 \mathrm{a}$ & 6433 \\
\hline $\mathrm{I}_{2}$ & $2523 \mathrm{~b}$ & $2345 \mathrm{~b}$ & $2072 b$ & 2313 & $6368 \mathrm{~b}$ & $5425 \mathrm{~b}$ & $5243 \mathrm{~b}$ & 5679 \\
\hline $\mathrm{I}_{3}$ & $2320 \mathrm{c}$ & $2150 \mathrm{c}$ & $1941 \mathrm{c}$ & 2137 & $5856 \mathrm{c}$ & $4936 \mathrm{c}$ & $4905 \mathrm{c}$ & 5232 \\
\hline D-Mean & 2568 & 2310 & 2090 & 2323 & 6487 & 5502 & 5356 & 5782 \\
\hline \multicolumn{9}{|c|}{ In a column, followed by a common letter are not significantly different at the 5 level by DMRT } \\
\hline Comparison & & S.E.D & $\begin{array}{l}\text { LSD } \\
(5 \%)\end{array}$ & $\begin{array}{l}\text { LSD } \\
(\mathbf{1 \%})\end{array}$ & & S.E.D & $\mathbf{L S D}(\mathbf{5})$ & LSD (1) \\
\hline 2-D means at each I & & 8.66 & 20.23 & 29.80 & & 98.42 & 220.32 & 315.72 \\
\hline 2-I means at each D & & 6.00 & 12.62 & 17.28 & & 93.58 & 196.61 & 369.37 \\
\hline
\end{tabular}

\section{Effect of sowing date:}

Mean values of spike length in $\mathrm{cm}$ of wheat as affected by sowing date are shown in Table (9) Sowing date significantly influenced spike length. Mean values of spike length obtained by $\mathrm{D}_{1}, \mathrm{D}_{2}$ and $\mathrm{D}_{3}$ sowing date are $11.2,9.2$ and $8.2 \mathrm{~cm}$ respectively Table (9) values of spike length under all the sowing date treatments had the descending order: $\quad D_{1}>D_{2}>D_{3}$. The decrease percentage on spike length was $(17.8 \%$ and $26.7 \%)$ under $D_{2}$ and $D_{3}$, respectively, compared with treatment $\mathrm{D}_{1}$.It means that sowing date in $15^{\text {th }}$ November cause higher increase on spike length compared with other sowing dates.

\section{Effect of irrigation number:}

Regarding the effect of irrigation number treatments, spike length was greater with $I_{1}$ treatment than the other two irrigation number treatments. This occurred under each of the sowing date .Table (9) show that mean spike length due to irrigation number of $\mathrm{I}_{1}, \mathrm{I}_{2}$ and $\mathrm{I}_{3}$ were $11.3,9.4$ and $7.8 \mathrm{~cm}$ respectively. Thus the $\mathrm{I}_{1}$ treatment gave the highest yield. $\mathrm{I}_{1}$ significantly increased spike length by 16.8 and $30.9 \%$ compared to $\mathrm{I}_{3}$.
Effect of interaction between sowing date and irrigation number:

The highest spike length was obtained by $I_{1} D_{1}$ treatment which gave $13.3 \mathrm{~cm}$ The lowest spike length was obtained by the $\mathrm{I}_{3} \mathrm{D}_{3}$ treatment which gave $7.0 \mathrm{~cm}$. Further delay in sowing resulted in shorter spike length. Irrigation number and its interaction with sowing time hade significant effect on spike length (Table-9), however, longer spike length of $13.3 \mathrm{~cm}$ was noted on $15^{\text {th }}$ November with five irrigation. Waraich et al. (1981) reported that earlier planting resulted in better spike development due to longer growing period.

Number of tillers $\left(\mathrm{m}^{-2}\right)$ :

The economic yield of most of the cereals is determined by the number of tillers. It has the great agronomic importance as this may compensate the difference in number of plants, partially or totally after crop establishment and may allow crop recovery.

\section{Effect of sowing date}

Mean values of the number of tillers of wheat as affected by sowing date are shown in Table (9) sowing date significantly influenced the number of tillers. Mean values of the number of tillers obtained by $\mathrm{D}_{1}, \mathrm{D}_{2}$ and $\mathrm{D}_{3}$ sowing date are $175.7,162.3$ and 144.4 
. respectively Table( 9) values of the number of tillers under all the sowing date treatments had the descending order: $D_{1}>D_{2}>D_{3}$. The decrease percentage in the number of tillers was $(7.6 \%$ and $17.8 \%)$ under $\mathrm{D}_{2}$ and $\mathrm{D}_{3}$, respectively, compared with treatment $\mathrm{D}_{1}$.It means that sowing date in $15^{\text {th }}$ November cause higher increase in the number of tillers compared with other sowing dates.

\section{Effect of irrigation number:}

Regarding the effect of irrigation number treatments, the number of tillers was greater with $\mathrm{I}_{1}$ treatment than the other two irrigation the number of tillers. This occurred under each of the sowing date since the interaction between the irrigation number treatment and sowing date was significant Table (9). Mean the number of tillers due to irrigation number of $\mathrm{I}_{1}, \quad \mathrm{I}_{2}$ and $\mathrm{I}_{3}$ were $180.0,159.6$ and $142.8 \mathrm{~cm}$ respectively .. Thus the $\mathrm{I}_{1}$ treatment gave the highest yield. $I_{1}$ significantly increased the number of tillers by 11.3 and $20.6 \%$ compared to $\mathrm{I}_{3}$.

Effect of interaction between sowing date and irrigation number:

The highest number of tillers was obtained by $I_{1} D_{1}$ treatment which gave 208.3 The lowest number of tillers was obtained by the $\mathrm{I}_{3} \mathrm{D}_{3}$ treatment which gave $144.4 \mathrm{~cm}$.

Further delay in sowing resulted in lowest number of tillers. Irrigation number and its interaction with sowing time hade significant effect on the number of tillers Table (9), however, highest the number of tillers of 208.3 was noted on $15^{\text {th }}$ November with five irrigation.

Plant height at maturity (cm):

Height of the crop is mainly controlled by the genetic makeup of a genotype and it can also be affected by the environmental factors (Shahzad et al., 2007)

Table (9) Effect of sowing date (D) and irrigation number (I) on spike length $(\mathrm{cm})$ and number of tiller during 2014/2015 growing seasons.

Treatments

Spike length cm

Number of tiller (number)

\begin{tabular}{lcccccccc} 
& $\mathrm{D}_{1}$ & $\mathrm{D}_{2}$ & $\mathrm{D}_{3}$ & $\mathrm{I}-$-mean & $\mathrm{D}_{1}$ & $\mathrm{D}_{2}$ & $\mathrm{D}_{3}$ & I-mean \\
\hline $\mathrm{I}_{1}$ & $13.3 \mathrm{a}$ & $11.3 \mathrm{a}$ & $9.5 \mathrm{a}$ & 11.3 & $208.3 \mathrm{a}$ & $177.3 \mathrm{a}$ & $154.5 \mathrm{a}$ & 180.0 \\
$\mathrm{I}_{2}$ & $11.0 \mathrm{~b}$ & $9.3 \mathrm{~b}$ & $8.0 \mathrm{~b}$ & 9.4 & $169.3 \mathrm{~b}$ & $165.3 \mathrm{~b}$ & $144.3 \mathrm{~b}$ & 159.6 \\
$\mathrm{I}_{3}$ & $9.3 \mathrm{c}$ & $7.0 \mathrm{c}$ & $7.0 \mathrm{c}$ & 7.8 & $149.5 \mathrm{c}$ & $144.3 \mathrm{c}$ & $134.5 \mathrm{c}$ & 142.8 \\
$\mathrm{D}-$-Mean & 11.2 & 9.2 & 8.2 & 9.5 & 175.7 & 162.3 & 144.4 & 160.8 \\
\hline
\end{tabular}

\section{Effect of sowing date}

Data showed that plant height differed significantly by sowing date Mean values of the plant height of wheat as affected by sowing date are shown in Table (10) Sowing date significantly influenced the plant height. Mean values of the plant height obtained by $\mathrm{D}_{1}, \mathrm{D}_{2}$ andD $\mathrm{D}_{3}$ sowing date are $78.2,72.7$ and $70.4 \mathrm{~cm}$ respectively. values of the plant height under all the sowing date treatments had the descending order: $D_{1}>D_{2}>D_{3}$. The decrease percentage on the number of tillers was $(7.0 \%$ and $9.9 \%)$ under $\mathrm{D}_{2}$ and $\mathrm{D}_{3}$, respectively, compared with treatment $\mathrm{D}_{1}$.It means that sowing date in $15^{\text {th }}$ November cause higher increase on plant height compared with other sowing dates.

Effect of irrigation number:

Regarding the effect of irrigation number treatments, plant height was greater with $I_{1}$ treatment than the other two irrigation. Mean the plant height due to irrigation number of $I_{1}, I_{2}$ and $I_{3}$ were $79.5,75.8$ and $65.9 \mathrm{~cm}$ respectively. Thus the $\mathrm{I}_{1}$ treatment gave the longest plant height. $\mathrm{I}_{1}$ significantly increased plant height by 6.9 and $17.1 \%$ compared to $\mathrm{I}_{3}$.
Effect of interaction between sowing date and irrigation number:

The longest plant height was obtained by $\mathrm{I}_{1} \mathrm{D}_{1}$ treatment which was 87.0 The lowest plant height was obtained by the $\mathrm{I}_{3} \mathrm{D}_{3}$ treatment which gave $64.3 \mathrm{~cm}$.

The wheat crop sown on $15^{\text {th }}$ November produced the tallest plants of $87.0 \mathrm{~cm}$ respectively. In case of irrigation number, the maximum plant height $(87.0 \mathrm{~cm})$ was observed with five irrigation number followed by four irrigation number which produced plants of 78.3 $\mathrm{cm}$. has results.

1000-grain weight $(\mathrm{g})$ :

Among different sowing dates, the maximum 1000 -grain weight $(44.3 \mathrm{~g})$ was recorded on $15^{\text {th }}$ November. The minimum 1000-grain weight (35.3 g) was noted on $15^{\text {th }}$ December sowing date. The decrease percentage on 1000-grain weight was $(20.3 \%)$ under $\mathrm{D}_{3}$, compared with treatment $\mathrm{D}_{1}$ Among number of irrigation, the maximum 1000-grain weight (44.9 g) was obtained when five irrigation was done. The results are in agreement with the findings of Shahzad et al. (2007) who also observed that earlier sowing resulted in better development of the grain due to longer growing period 
Table (10) Effect of sowing date (D) and irrigation number (I) on plant height (cm) and Weigh of 1000 grain(gm) during 2014/2015 growing season.

\begin{tabular}{|c|c|c|c|c|c|c|c|c|}
\hline \multirow[t]{2}{*}{ Treatments } & \multicolumn{4}{|c|}{ Plant high(cm) } & \multicolumn{4}{|c|}{ Weigh of 1000 grain(gm) } \\
\hline & $\mathrm{D}_{1}$ & $\mathrm{D}_{2}$ & $\mathrm{D}_{3}$ & I-mean & $\mathrm{D}_{1}$ & $\mathrm{D}_{2}$ & $\mathrm{D}_{3}$ & I-mean \\
\hline $\mathrm{I}_{1}$ & $87.0 \mathrm{a}$ & $79.3 \mathrm{a}$ & $72.3 \mathrm{a}$ & 79.5 & $49.3 \mathrm{a}$ & $45.3 \mathrm{a}$ & $40.3 \mathrm{a}$ & 44.9 \\
\hline $\mathrm{I}_{2}$ & $78.3 \mathrm{~b}$ & $74.5 \mathrm{~b}$ & $74.5 \mathrm{~b}$ & 75.8 & $45.3 \mathrm{~b}$ & $40.3 \mathrm{~b}$ & $35.3 \mathrm{~b}$ & 40.3 \\
\hline $\mathrm{I}_{3}$ & $69.3 \mathrm{c}$ & $64.3 \mathrm{c}$ & $64.3 \mathrm{c}$ & 65.9 & $39.3 \mathrm{c}$ & $35.3 \mathrm{c}$ & $30.5 \mathrm{c}$ & 35.0 \\
\hline D-Mean & 78.2 & 72.7 & 70.4 & 72.5 & 44.3 & 40.3 & 35.3 & 40.1 \\
\hline \multicolumn{9}{|c|}{ In a column, followed by a common letter are not significantly different at the 5 level by DMRT } \\
\hline Comparison & & S.E.D & LSD(5) & LSD (1) & & S.E.D & LSD(5) & LSD (1) \\
\hline 2-D means at each $I$ & & 0.5 & 1.0 & 1.4 & & 0.1 & 0.3 & 0.4 \\
\hline 2-I means at each D & & 0.5 & 1.1 & 1.4 & & 0.1 & 0.2 & 0.3 \\
\hline
\end{tabular}

Water productivity (WP)

Water productivity is considered as an evaluation parameter of yield per unit of applied water, i.e., WP is a tool for maximizing crop production per each unit of applied water. Water productivity of wheat was evaluated for both grain and straw yield in $\mathrm{kg} \mathrm{m}^{-3}$. The data obtained are presented in Tables (11, and 12)

Results showed that amounts of $\mathrm{WP}_{\mathrm{g}}$ were $1.16,1.26$ and $1.39 \mathrm{~kg}$ grain $\mathrm{m}^{-3}$ resulted from number of irrigation treatments $I_{1}, I_{2}$ and $I_{3}$ respectively From the presented data, it is clear that values of WP of wheat differed from one treatment to another as affected by number of irrigation.

Regarding sowing date, Tables (11\& 12) reveal that $D_{1}$ treatment achieved the highest amounts of water productivity i.e. $1.28 \mathrm{~kg}$ grain $\mathrm{m}^{-3}$ as compared to $\mathrm{D}_{2}$ and $\mathrm{D}_{3} \quad\left(1.29\right.$ and $1.24 \mathrm{~kg}$ grain $\left.\mathrm{m}^{-3}\right)$

Table (11): Amounts of irrigation water applied, grain yield, straw yield, water productivity of wheat grain $\left(\mathrm{WPg} \mathrm{k} \mathrm{m}^{-3}\right.$ ) and water productivity of wheat straw (WPs $\mathrm{kg} \mathrm{m}^{-3}$ ) during 2014/2015 growing season

\begin{tabular}{|c|c|c|c|c|c|c|}
\hline Treatments & & $\begin{array}{c}\text { Wa } \\
\text { m }^{3} \text { fed }^{-1}\end{array}$ & $\begin{array}{c}\text { Grain } \\
\text { yield } \\
\text { kgfed }^{-1}\end{array}$ & $\begin{array}{c}\text { Straw } \\
\text { yield } \\
\text { kgfed }^{-1}\end{array}$ & $\begin{array}{l}\text { WPg } \\
\mathrm{kgm}^{-3}\end{array}$ & $\begin{array}{c}\text { WPs } \\
\mathrm{kgm}^{-3}\end{array}$ \\
\hline \multirow{3}{*}{$\mathrm{D}_{1}$} & $\mathrm{I}_{1}$ & 2355.36 & 2861 & 3921.60 & 1.21 & 1.66 \\
\hline & $\mathrm{I}_{2}$ & 1922.64 & 2523 & 3640.80 & 1.31 & 1.89 \\
\hline & $\mathrm{I}_{3}$ & 1738.32 & 2320 & 3513.60 & 1.33 & 2.02 \\
\hline \multirow{3}{*}{$\mathrm{D}_{2}$} & $\mathrm{I}_{1}$ & 2141.76 & 2434 & 3326.40 & 1.14 & 1.55 \\
\hline & $\mathrm{I}_{2}$ & 1802.76 & 2345 & 3255.00 & 1.30 & 1.81 \\
\hline & $\mathrm{I}_{3}$ & 1498.32 & 2150 & 3141.60 & 1.43 & 2.10 \\
\hline \multirow{3}{*}{$\mathrm{D}_{3}$} & $\mathrm{I}_{1}$ & 2021.76 & 2258 & 3132.00 & 1.12 & 1.55 \\
\hline & $\mathrm{I}_{2}$ & 1754.88 & 2072 & 3025.80 & 1.18 & 1.72 \\
\hline & $\mathrm{I}_{3}$ & 1378.32 & 1941 & 2943.00 & 1.41 & 2.14 \\
\hline
\end{tabular}

Table (12) water productivity of wheat grain (WPg) and straw(WPs) $\left(\mathrm{kg} \mathrm{m}^{-3}\right)$ as related to interaction between sowing date and number of irrigation in the 2014/2015 growing season.

\begin{tabular}{lcccccccc}
\hline \multirow{2}{*}{ Treatments } & \multicolumn{3}{c}{ WPg kgm $^{-3}$} & \multicolumn{4}{c}{ WPs kgm $^{-3}$} \\
& $\mathrm{D}_{1}$ & $\mathrm{D}_{2}$ & $\mathrm{D}_{3}$ & $\mathrm{I}-$ mean & $\mathrm{D}_{1}$ & $\mathrm{D}_{2}$ & $\mathrm{D}_{3}$ & I-mean \\
\hline $\mathrm{I}_{1}$ & 1.21 & 1.14 & 1.12 & 1.16 & 1.66 & 1.55 & 1.55 & 1.59 \\
$\mathrm{I}_{2}$ & 1.31 & 1.30 & 1.18 & 1.26 & 1.89 & 1.81 & 1.72 & 1.81 \\
$\mathrm{I}_{3}$ & 1.33 & 1.43 & 1.41 & 1.39 & 2.02 & 2.10 & 2.14 & 2.09 \\
D-Mean & 1.28 & 1.29 & 1.24 & & 1.86 & 1.82 & 1.80 & \\
\hline
\end{tabular}

\section{CONCLUSION}

It could be concluded that irrigation at short intervals ( 5 irrigations),sowing date on $15^{\text {th }}$ November and variety Masr 2 could produce higher number of tillers, spike length, plant height, 1000-grain weight and straw and grain yield in North Nile Delta-Egypt

\section{REFERENCES}

Allen RG, LS.Pereira, D.Raes, and M.Smith (1998). Crop evapotranspiration: guidelines for computing crop water requirements. FAO Irrigation and drainage paper No. 56. Rome, Italy: FAO.

Doorenbos J.; A. H. Kassam; C.L. M. Bentvelson and V. Broncheid (1978). Yield response to water. FAO Irrigation and drainage Paper, No. 33 Rome. 
Doorenbos, J. and W. O. Pruitt (1975). Crop water requirements. FAO Irrigation and drainage Paper, No. 24 Rome.

Doorenbos, J.; A. H. Kassam; C.L. M. Bentvelson and V. Broncheid (1979). Yield response to water. FAO Irrigation and drainage Paper, No. 33 Rome.

Eid,S.Mona.(2015) Effect of irrigation deficit and wide furrows on wheat water relations and yield, and soil properties in North Nile Delta._PhD thesis, Fac. Of Agric. Mansoura Univ.

El-Marsafawy, S.M., M.A. Ali, A.Y. Salib, and H.M.Eid, 1998. Effect of different sowing dates on some wheat varieties yield and their water relations. The 2nd conference for Meteorology and Sustainable Development. Feb. 1998.

Eid, H.M.S. M. El-Marsafawy, M.A. Ali, N.G. Ainer,A. A. Rayan and O. El-Kholi,1997. Vulnerability and adaptation to climate change in wheat crop.Meteorology and Environmental Cases. Conf.pp.152-165. March, 1997. Egypt

Giriappa, S. (1983). Water use efficiency in agriculture. Oxford-IBH Publishing Co.,New Delhi.

Gomez, K.A and A.Gomez (1984). Statistical procedures for agricultural research. $1^{\text {st }}$ ed. John Wiley Sons, New Yourk.
Hansen, V.W.; D.W. Israelsen and D.E. Stringharm (1980). Irrigation Principle and Practices, 4th ed. Johns Wiley \& Sons., New York.

Molden, D., (1997). Accounting for water use and productivity. SWIM Paper 1. International Irrigation Management Institute, Colombo, Sri Lanka.

Ouda S.A.;S.M. El-Marsafawy;M.A. El-Kholy and M.S. Gaballah (2005). Simulating the effect of Water Stress and Different Sowing Dates on Wheat Production in South Delta. Journal of Applied Sciences Research 1(3): 268-276,

Shahzad, M A., W. U. Din, S. T. Sahi, M. M. Khan,Ehsanullah and M. Ahmad (2007). Effect of sowing dates and seed treatment on grain yield and quality of wheat. Pakistan J. Agri. Sci. 44(4): 581-583.

Smith, M. (1992). CROPWAT-a computer program for irrigation planning and management. FAO Irrigation and Drainage Paper 46, p. 126,ISBN 92-5-103106-1.

Waller, R.A. and D.B.Duncan. (1969). Symmetric multiple Comparison Problem. Amer. Stat.Assoc. Jour.December, 1485-1503.

Zhang, H. and Oweis, T. (1999). Water-yield relations and optimal irrigation scheduling of wheat in the Medi-terranean region. Agricultural Water Management, 38, 195-211 .

\footnotetext{
تأثير تاريخ زراعه القمح تحت ظروف الاجهاد المائى فى شمال دلتا النيل- مصر

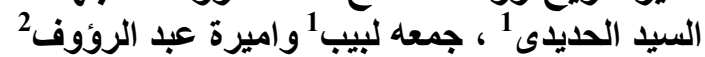

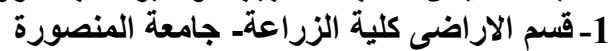

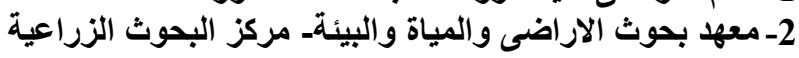

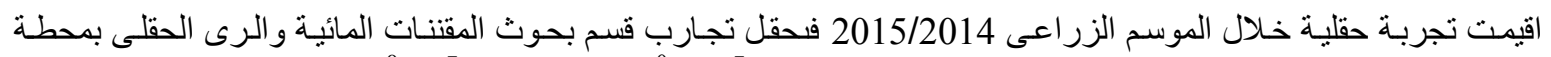

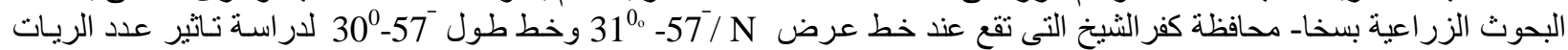

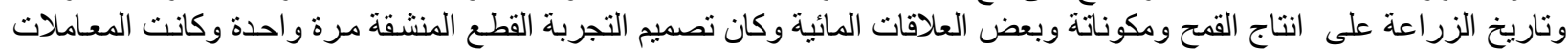

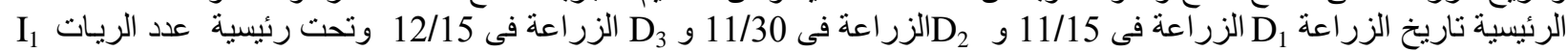

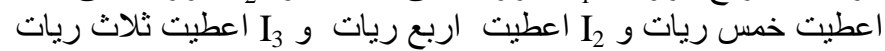

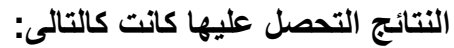

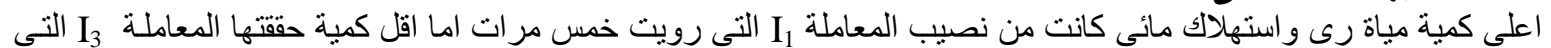

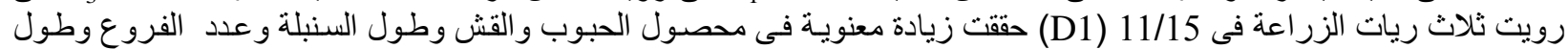

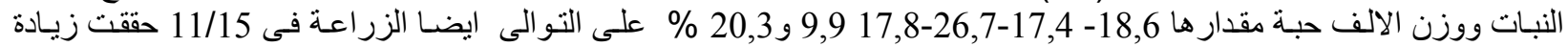

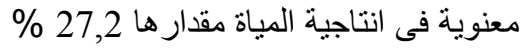

